\title{
Community ecology of epiphytic Bromeliaceae in a remnant of Atlantic Forest in Zona da Mata, Minas Gerais State, Brazil ${ }^{1}$
}

\author{
Geicilaine Alves Basílio², Daniel Elias Ferreira Barbosa², Samyra Gomes Furtado ${ }^{3}$, \\ Fernando Rodrigues Silva ${ }^{2}$ and Luiz Menini Neto ${ }^{2,3,4}$
}

Received: 13.12.2013; accepted: 2.07.2014

\begin{abstract}
Community ecology of epiphytic Bromeliaceae in a remnant of Atlantic Forest in Zona da Mata, Minas Gerais State, Brazil). The present study aimed to document the composition, richness, diversity as well as horizontal and vertical distribution of epiphytic Bromeliaceae in a fragment of submontane seasonal semideciduous forest in Minas Gerais State $\left(-21^{\circ} 38^{\prime} 15^{\prime \prime} \mathrm{S},-43^{\circ} 10^{\prime} 55^{\prime \prime} \mathrm{W}\right)$. Three plots (semicircles with a radius of $25 \mathrm{~m}$ ) were marked and we found 72 phorophytes that harbor 15 species of epiphytic Bromeliaceae, distributed in nine genera. Nidularium azureum (L.B.Sm.) Leme is local endemic, and considered critically endangered. In general, the richness is higher than other larger areas of seasonal semideciduous or even ombrophilous forests. Some differences concerning composition, diversity and richness among the plots were found and must be due to microhabitat conditions. Trunks supported most occurrences (101 out of 246) and Tillandsia stricta Sol. ex Sims had the highest frequency on the phorophytes. The values of $\mathrm{H}^{\prime}=2.34$ and $\mathrm{J}=0.87$ must be considered similar or even higher than some ombrophilous forests.

Keywords: epiphytes, horizontal distribution, Pielou equability index, seasonal semideciduous forest, Shannon diversity index, vertical distribution
\end{abstract}

RESUMO - (Ecologia da comunidade de Bromeliaceae epifíticas em um remanescente de Floresta Atlântica, MG, Brasil) O presente estudo teve como objetivo documentar a composição, riqueza, diversidade, bem como a distribuição horizontal e vertical de Bromeliaceae epífitas em um fragmento de floresta estacional semidecidual submontana no Estado de Minas Gerais (-21 $\left.{ }^{\circ} 38^{\prime} 15^{\prime \prime} \mathrm{S},-43^{\circ} 10^{\prime} 55^{\prime \prime} \mathrm{W}\right)$. Três pontos (semicírculos com raio de $25 \mathrm{~m}$ ) foram delimitados, e 72 forófitos abrigaram 15 espécies de Bromeliaceae epifíticas, distribuídas em nove gêneros. Nidularium azureum (L.B.Sm.) Leme é uma espécie endêmica local e considerada "criticamente em perigo". Em geral, a riqueza é mais alta do que em outras localidades, com área maior tanto em florestas estacionais semideciduais quanto ombrófilas. Foram encontradas algumas diferenças quanto à composição, diversidade e riqueza entre os três pontos, as quais devem estar relacionadas às condições de microhabitats. Os troncos das árvores concentraram o maior número de ocorrências (101 das 246) e Tillandsia stricta Sol. ex Sims teve a maior frequência nos forófitos. Os valores de $\mathrm{H}^{\prime}=2,34 \mathrm{e} J=0,87$ podem ser considerados similares ou mesmo mais altos do que em algumas florestas ombrófilas.

Palavras-chave: epífitas, distribuição horizontal, distribuição vertical, floresta estacional semidecidual, índice de diversidade de Shannon, índice de equabilidade de Pielou

\section{Introduction}

Bromeliaceae is composed of nearly 52 genera and 3320 species (The Plant List 2013) distributed in the subfamilies Brocchinioideae, Bromelioideae, Hechtioideae, Lindmanioideae, Navioideae,
Pitcairnioideae, Puyoideae and Tillandsioideae (Givnish et al. 2011), presenting essentially a Neotropical distribution (Smith \& Downs 1974). Brazil harbors 44 genera and about 1307 species and the Atlantic Forest must be highlighted, in which Bromeliaceae is the fourth most diverse family,

1. Parte do Trabalho de Conclusão de Curso do primeiro Autor, Curso de Ciências Biológicas do Centro de Ensino Superior de Juiz de Fora, SP, Brazil

2. Centro de Ensino Superior de Juiz de Fora, Campus Arnaldo Janssen, Luz Interior 345, Santa Luzia, 36030-776 Juiz de Fora, MG, Brazil

3. Universidade Federal de Juiz de Fora, Instituto de Ciências Biológicas, Departamento de Botânica, 36036-900 Martelos, Juiz de Fora, MG, Brazil

4. Corresponding author: menini.neto@gmail.com 
assembling a total of 30 genera and 896 species (Forzza et al. 2014). Minas Gerais is the third richest Brazilian State in Bromeliaceae, and comprises 27 genera and 265 species and 18 infraspecific taxa, of which $102(36 \%)$ are endemic to the State and 97 (34\%) are exclusive to the Atlantic Forest (Versieux $\&$ Wendt 2007).

Furthermore, Bromeliaceae is one of the richest families among epiphytes in a tropical environment, besides Orchidaceae and Polypodiaceae (Zotz 2013), and it is found in a wide range of altitudes, temperature and humidity conditions, being often characteristic or facultative epiphytes (Benzing 2000).

In Brazil, studies on the composition and/or structure of epiphytes have been focused on the Atlantic Forest of the southern and southeastern regions, although the latter region is less represented (Kersten 2010). In such studies, Bromeliaceae is often referred to as the second or third family in specific richness, and in some cases it is cited as the richest one (Perleberg \& Tomkowski 2007, Dettke et al. 2008, Hobus et al. 2008), highlighting its importance in the structure of the epiphytic component of the Atlantic Forest.

The Atlantic Forest is considered a world biodiversity hotspot due to the high number of animal and plant species, of which several are endemic and/ or are threatened (Myers et al. 2000). Currently, only $11-16 \%$ of the original cover remains (Ribeiro et al. 2009), and despite this intense fragmentation and reduction, several studies point out the great richness of plant and animal groups in this phytogeographic domain, which contains, for example, about 16000 species of plants (Stehmann et al. 2009, Forzza et al. 2012). These factors make the area a high priority for conservation of worldwide biodiversity (Ministério do Meio Ambiente 2013). In Minas Gerais State, the vegetation cover of the Atlantic Forest, especially in the region of Zona da Mata, which harbored a forest extending between the Paraíba River to the south and the Doce River ou river valley to the north, has been significantly altered since the 19th century due to coffee crops, resulting in a significant impact on the natural landscape (Valverde 1958, Saraiva 2005).

One of the rare forest fragments of great extension in this region lies in Fazenda Fortaleza de Sant'Anna (FFS), located in the microregion of Juiz de Fora, among the municipalities of Goianá, Coronel Pacheco, Chácara and São João Nepomuceno. This region is recognized by Drummond et al. (2005) as a priority for conservation of biodiversity in Minas Gerais based upon its very high biological importance. It comprises the "Corredor Sudeste" and is characterized by its high connectivity potential among vegetation remnants, which could form ecological corridors, besides being strongly threatened by deforestation.

Bromeliaceae plays a great role in terms of biodiversity in the Atlantic Forest, since they are a fundamental element to the establishment and maintenance of local flora and fauna, for example by providing resources such as food, shelter or nesting sites. So far, there have been no studies or reports on the quantitative aspects or vertical distribution of epiphytes in Zona da Mata of Minas Gerais, and very few studies about epiphytism in this State address vascular species (Werneck \& Espírito-Santo 2002, Alves et al. 2008, Alves \& Menini Neto 2014, Barbosa et al. 2015) or angiosperms (Menini Neto et al. 2009a).

The present study was aimed at evaluating the floristic composition and ecology of Bromeliaceae epiphytic species in a fragment of submontane seasonal semideciduous forest in the FFS, Zona da Mata in Minas Gerais State. Our analyses included richness, diversity, as well as the horizontal and vertical species distribution in order to enhance the knowledge of epiphytic flora in Minas Gerais State.

\section{Material and methods}

Study area - The Fazenda Fortaleza de Sant'Anna (FFS) is located at Serra da Babilônia among the municipalities of Goianá, Coronel Pacheco, Chácara and São João Nepomuceno (figure 1), in the phytogeographic domain of the Atlantic Forest, harboring forest remnants, in addition to several springs and streams which are tributaries of the Basin of Paraíba do Sul River (PREA 2012).

The FFS has an area of about 4,684 ha, of which ca. 2,238 ha comprise vegetation characterized by remnants of submontane seasonal semideciduous forest (Veloso et al. 1991, PREA 2012).

Based upon studies performed in Goianá in Minas Gerais State, the regional climate is characterized as Cwa (humid subtropical) according to Köppen classification, with dry winters and warm and humid summers. Such climate is influenced by a relief composed of hills which vary in height between 450 and $900 \mathrm{~m}$. The mean annual temperature is $21^{\circ} \mathrm{C}$. In the coldest and warmest months, the temperature ranges from 15.3 to $27.9{ }^{\circ} \mathrm{C}$, respectively. The mean annual precipitation is about $1.581 \mathrm{~mm}$ (PREA 2012). 
Field and laboratory work - This study was carried out on April, August and September 2012 in a forest fragment adjacent to Cágado River, in the portion of the FFS belonging to municipality of Chácara $\left(-21^{\circ} 38^{\prime} 15^{\prime \prime} \mathrm{S},-43^{\circ} 10^{\prime} 55^{\prime \prime} \mathrm{W}\right)$, located approximately $25 \mathrm{~km}$ from Juiz de Fora (figure 1).

The data were obtained in three points situated near the river approximately $100 \mathrm{~m}$ from each other [plot 1 (P1) in the east margin, plot 2 (P2) and plot 3 (P3) in the west margin], where semicircles with a radius of $25 \mathrm{~m}$ were marked. All phorophytes within the semicircle of at least $10 \mathrm{~cm}$ in diameter at $1.3 \mathrm{~m}$ heights were analyzed. Whenever necessary, the plants were collected and their relevant data registered, being herborized according to usual methodology. The voucher specimens were deposited in the Herbarium CESJ of the Universidade Federal de Juiz de Fora (acronym according to Thiers 2013).

Species were identified through comparison with specimens housed in the Herbarium CESJ, as well as consultation with literature and via collaboration with a specialist in the family Bromeliaceae. The names of the species and authors were checked through consultation with the International Plant Names Index (IPNI 2012).

The species were classified into ecological categories according to their relationship with the phorophyte (Benzing 1990). However, in this study, only two categories were found: characteristic holoepiphytes and facultative holoepiphytes.

In order to analyze the vertical distribution of the bromeliads, the phorophytes were divided into five strata: A - lower trunk: lower half of the trunk; B upper trunk: upper half of the trunk; $\mathrm{C}$ - internal crown: first ramification of the crown; D - median crown: second ramification of the crown; and E - external crown: external branches of the crown (figure 2).

Statistical analyses - The absolute and relative frequencies of the species were calculated to evaluate their occurrence in the phorophytes and respective strata.

Similarity analysis through Unweighted PairGroup Method with Arithmetic Mean (UPGMA) using the Jaccard index and rarefaction curves $(95 \%$ confidence) were performed in order to compare, respectively, the composition and richness of species among the three plots.

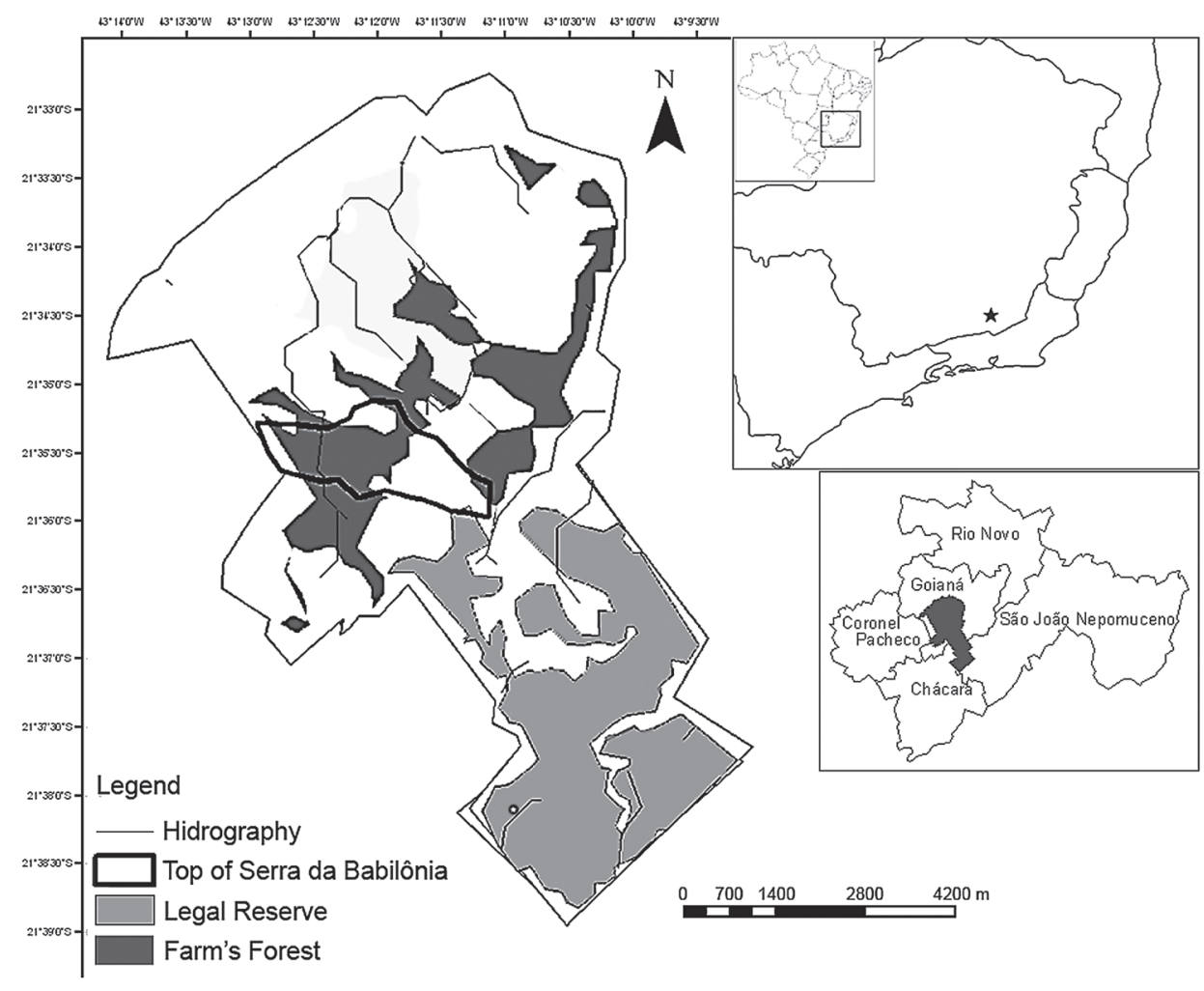

Figure 1. Location of Fazenda Fortaleza de Sant'Anna, Minas Gerais State, Brazil and the surveyed points ( $\varnothing$ ). Font: modified of PREA (2012). 
Also, the alpha diversity was calculated by using the Shannon index $\left(H^{\prime}\right)$ for all the three plots and separately for each plot, according to the formula presented by Kersten \& Waechter (2009). Moreover, we calculated the Pielou equitability index $(J)$ in order to evaluate the uniformity among the species occurring in the plots. The Hutchinson t-test (Magurran 2011) was used to compare the values of $H^{\prime}$ found in each plot $(p<0.05)$.

The statistical analyses were conducted using the softwares PAST v. 2.17 (Hammer et al. 2001) and Microsoft Excel 2010 ${ }^{\circledR}$.

\section{Results and Discussion}

Floristics - We found 15 species of epiphytic Bromeliaceae in the three studied plots, belonging to nine genera and two subfamilies, Bromelioideae and Tillandsioideae (table 1).

Bromelioideae presented the greatest number of genera (six) and species (eight): Aechmea nudicaulis (L.) Griseb., Aechmea sp., Billbergia distachia (Vell.) Mez, B. horrida Regel, Neoregelia farinosa (Ule) L.B.Sm., Nidularium azureum (L.B.Sm.) Leme, Portea petropolitana (Wawra) Mez and Quesnelia indecora Mez. Tillandsioideae was represented only by two genera, but with a number of species similar to Bromelioidae (seven): Tillandsia geminiflora Brongn.,
T. stricta Sol. ex Sims, T. usneoides (L.) L., Vriesea gigantea Gaudich., V. gradata (Baker) Mez, Vriesea sp. 1 and Vriesea sp. 2.

Barbosa et al. (2015) conducted a qualitative survey of vascular epiphytic species in about 1 ha of FFS which encompasses the area of the three studied plots and recorded 18 species of Bromeliaceae. Among the species listed by Barbosa et al. (2015), Acanthostachys strobilacea (Schult. \& Schult.f.) Klotzsch, Billbergia zebrina (Herb.) Lindl. and Tillandsia recurvata (L.) L. were not found in the present study. On the other hand, one species of Aechmea and one of Vriesea were not recorded by Barbosa et al. (2015), because they were not found fertile during field work.

In general, the geographic distribution of the identified species can be considered restricted. All but one species (Tillandsia usneoides) are endemic to Brazil, and six of the identified species occur exclusively in the Atlantic Forest (Billbergia horrida, Neoregelia farinosa, Nidularium azureum, Portea petropolitana, Quesnelia indecora and Vriesea gradata) and other three are also found in Cerrado (Aechmea nudicaulis, B. distachia and T. geminiflora) and one in Pampa ( $V$. gigantea) (Forzza et al. 2014). Regarding vegetation physiognomies, it is interesting that only two species are restricted to a

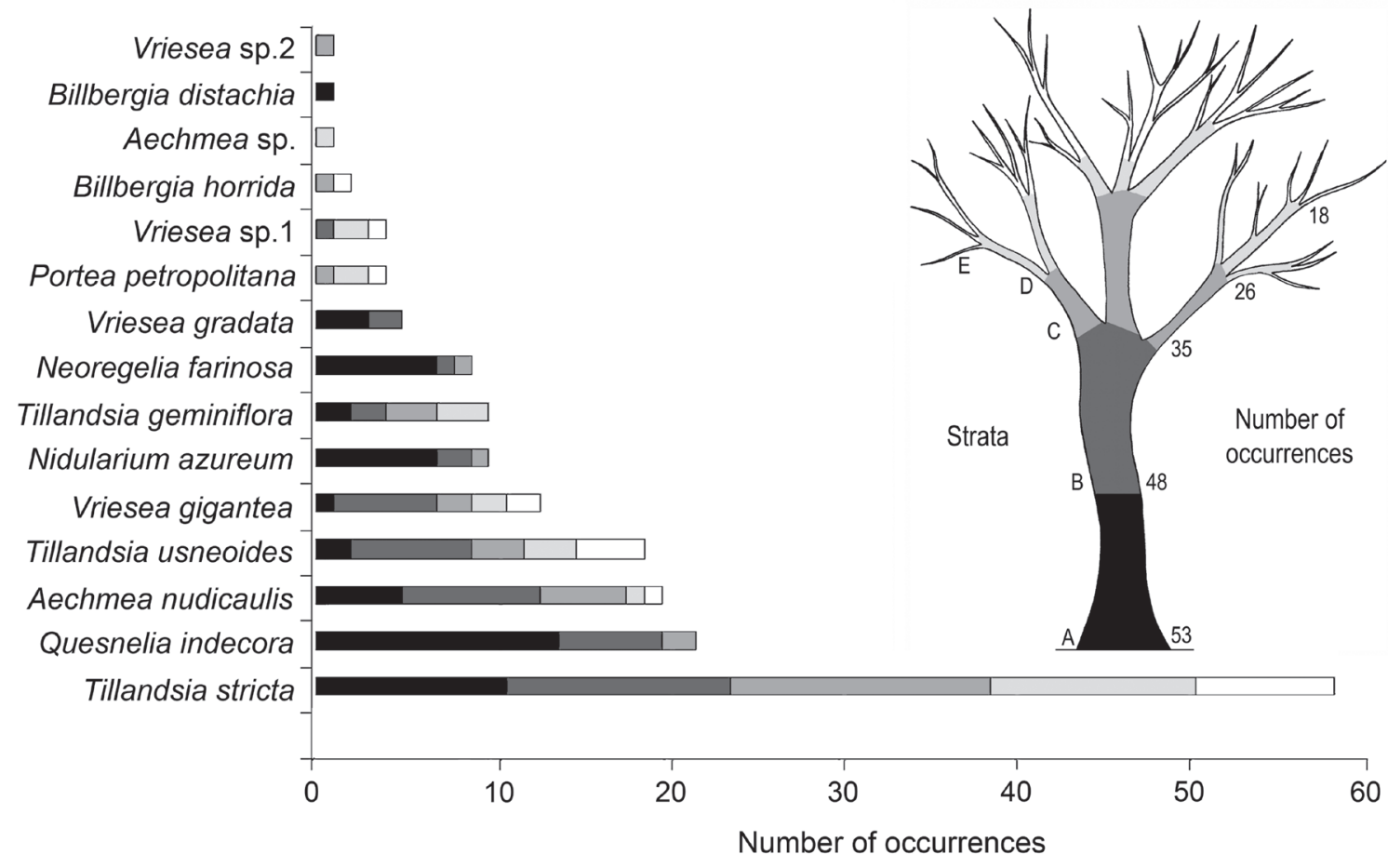

Figure 2. Occurrences of species of epiphytic Bromeliaceae by stratum, Minas Gerais State, Brazil. 
seasonal semideciduous forest (A. nudicaulis and $N$. azureum) and other two are considered to be exclusive of ombrophilous forests (both species of Vriesea), while four species can occur in both forest types (B. distachia, B. horrida, N. farinosa and $P$. petropolitana). Ombrophilous elements were noticed by Barbosa et al. (2015) also for Orchidaceae in FFS, including a new record to flora of Minas Gerais, Stelis oligantha Barb. Rodr., previously known only to the ombrophilous forests of Rio de Janeiro and São Paulo States. It is probably due to the influence of the river in the maintenance of species typical of moister areas in a physiognomy with a dryer environment such as semideciduous forests. Such influence of Dense Ombrophilous Forest were also found by Pifano et al. (2007) and Forzza et al. (2014), in two areas of FFS in Zona da Mata of Minas Gerais State.

Among the recorded species, we highlight Nidularium azureum since it is microendemic to this region, being previously collected only in the municipality of Coronel Pacheco (limitrophe to Chácara and where a part of FFS is located). Furthermore, it is at risk of extinction and cited in the red list of the flora of Minas Gerais State (Sano et al. 2008) and Red Book of Brazilian Flora (Forzza et al. 2013) as critically endangered.

Kersten (2010) pointed out that Bromeliaceae is numerous in seasonal forests, and Tillandsia is responsible for the bulk of this abundance. This genus is also the largest of Bromeliaceae, with more than 400 species distributed throughout the American continent (Reitz 1983). Tillandsia has often been found to be the most frequent in other studies (Pinto et al. 1995, Kersten \& Silva 2002, Gonçalves \& Waechter 2003, Giongo \& Waechter 2004, Fabricante et al. 2006), and Menini Neto et al. (2009a) highlighted it as the richest genus in a study that evaluated the floristic similarity of angiosperm epiphytes among 24 areas of the Brazilian southeastern and southern regions, of which the majority were in the Atlantic Forest.

The greater richness observed in the genus Vriesea (four spp.) possibly reflects the fact that this is one of the largest genus of Bromeliaceae and the richest of this family in the Atlantic Forest (Martinelli et al. 2008). The two identified species of this genus ( V. gigantea and $V$. gradata) are commonly found in

Table 1 - Species of epiphytic Bromeliaceae in Fazenda Fortaleza de Sant'Anna, Minas Gerais State, Brazil. N: Frequency of Bromeliaceae species on the phorophytes; AF: absolute frequency; RF: relative frequency Plots, occurrence of species in each one of the three studied plots, 1: present, 0: absent; EC: ecological category: CHL: characteristic holoepiphyte; FHL: facultative holoepiphyte; Disp: dispersion form; Zoo: zoocory; An: anemochory. Herbaria specimens: deposited in Herbarium CESJ; NC: not collected, because were found sterile.

\begin{tabular}{|c|c|c|c|c|c|c|c|c|c|}
\hline \multirow{2}{*}{ Species } & \multirow{2}{*}{$\mathrm{N}$} & \multirow{2}{*}{$\mathrm{AF}$} & \multirow{2}{*}{$\mathrm{RF}$} & \multicolumn{3}{|c|}{ Plots } & \multirow{2}{*}{$\mathrm{EC}$} & \multirow{2}{*}{ Disp } & \multirow{2}{*}{ Herbaria specimens } \\
\hline & & & & 1 & 2 & 3 & & & \\
\hline Tillandsia stricta Sol. ex Sims & 32 & 44.4 & 25.2 & 1 & 1 & 1 & CHL & An & Barbosa 46 \\
\hline Quesnelia indecora $\mathrm{Mez}$ & 16 & 22.2 & 12.6 & 1 & 1 & 1 & FHL & Zoo & Barbosa 8 \\
\hline Aechmea nudicaulis (L.) Griseb. & 16 & 22.2 & 12.6 & 1 & 1 & 0 & CHL & Zoo & Barbosa 93 \\
\hline Vriesea gigantea Gaudich. & 11 & 15.3 & 8.7 & 1 & 1 & 0 & FHL & An & Barbosa 24 \\
\hline Nidularium azureum (L.B.Sm.) Leme & 9 & 12.5 & 7.1 & 1 & 1 & 1 & FHL & Zoo & Barbosa 76 \\
\hline Neoregelia farinosa (Ule) L.B.Sm. & 8 & 11.1 & 6.3 & 1 & 1 & 1 & FHL & Zoo & Barbosa 127 \\
\hline Tillandsia geminiflora Brongn. & 8 & 11.1 & 6.3 & 1 & 1 & 0 & CHL & An & Barbosa 130 \\
\hline Tillandsia usneoides (L.) L. & 8 & 11.1 & 6.3 & 0 & 1 & 1 & CHL & An & Barbosa 105 \\
\hline Portea petropolitana (Wawra) Mez & 5 & 6.9 & 3.9 & 1 & 1 & 1 & CHL & An & Barbosa 134 \\
\hline Vriesea gradata (Baker) Mez & 4 & 5.6 & 3.2 & 1 & 0 & 1 & CHL & An & Barbosa 64 \\
\hline Vriesea sp. 1 & 4 & 5.6 & 3.2 & 1 & 1 & 0 & CHL & An & $\mathrm{NC}$ \\
\hline Aechmea sp. & 2 & 2.8 & 1.6 & 1 & 0 & 0 & $\mathrm{CHL}$ & Zoo & $\mathrm{NC}$ \\
\hline Billbergia horrida Regel & 2 & 2.8 & 1.6 & 0 & 0 & 1 & CHL & Zoo & Barbosa 137 \\
\hline Billbergia distachia (Vell.) Mez & 1 & 1.4 & 0.8 & 1 & 0 & 0 & FHL & Zoo & Barbosa 75 \\
\hline Vriesea sp. 2 & 1 & 1.4 & 0.8 & 0 & 1 & 0 & CHL & An & $\mathrm{NC}$ \\
\hline
\end{tabular}


seasonal semideciduous forests of the southeastern region of Brazil (Forzza et al. 2014). However, the inability to identify the other two species makes it difficult to draw more conclusions about the floristic composition.

Five species are facultative holoepiphytes (FHL), of which four belong to Bromelioideae, and 10 species are characteristic holoepiphytes (table 1). The predominance of characteristic holoepiphytes corroborates the results obtained for Bromeliaceae in seasonal semideciduous forests (Pinto et al. 1995, Bernardi \& Budke 2010, Bonnet et al. 2011) and it shows a pattern often found when analyzing the vascular epiphytes as a whole (Kersten 2010).

Although anemochory is the most frequent dispersal mechanism among epiphyte plants, in this study we found slightly more zoochoric species due to the greater richness of Bromelioideae, whose species possess fleshy fruits which are dispersed by animals (Smith \& Downs 1974, Givnish et al. 2011). This greater richness can be explained since this subfamily is richer than Tillandsioideae, regardless the life form (Martinelli et al. 2008, Fontoura et al. 2012). All these data also corroborate the assertion of Smith (1934) that the Atlantic Forest is the center of diversity for the subfamily Bromelioideae.

The richness of epiphytic Bromeliaceae found in FFS (a studied area of about $0.3 \mathrm{ha}$ ) could be considered high, when compared with other studies carried out in seasonal semideciduous forests or even other forest physiognomies (such as coastal forests [restingas] and dense or mixed ombrophilous forests) despite the smaller size and often fewer sampled phorophytes of the present a studied area. For example, in the Serra Negra (southeast of Minas Gerais), Menini Neto et al. (2009b) found 12 species in a fragment of alluvial dense ombrophilous forest of 0.9 ha. There are also studies about vascular epiphytes or exclusively about Bromeliaceae epiphytes in other Brazilian States. This includes the results of Fontoura et al. (2009) that recorded 11 species (occurring in 110 sampled phorophytes) and that of Mania \& Monteiro (2010) with 16 species in a coastal forest; both studies were performed in a 0.5 ha area. In fragments of mixed ombrophilous forest in the Brazilian southern region, studies recorded 11 species in 50 ha (Dittrich et al. 1999), 10 species in 475 ha (Gaiotto \& Acra 2005), and six species in an undefined size area (Buzatto et al. 2008). Bonnet et al. (2007) listed 14 species in fragments of dense ombrophilous forest in four stages of regeneration, also lacking the area size.
Even when compared with ecotonal areas, which are considered very rich because they harbor plants of both physiognomies (Bianchi et al. 2012), the flora of Bromeliaceae epiphytes of FFS is remarkable. Bernardi \& Budke (2010) and Geraldino et al. (2010) found two in 0.4 ha and 499 phorophytes as well as eight species in 30 ha and 80 phorophytes, respectively, in studies conducted in areas of transition among mixed ombrophilous and seasonal semideciduous forests of the Brazilian southern region.

A comparison with available data regarding studies of epiphytes in seasonal semideciduous forests in the Brazilian southern and southeastern regions make the numbers of FFS even more relevant (table 2), especially if considered that the size of the study area (0.3 ha) and/or number of analyzed phorophytes (72) are the smallest among the areas.

Quantitative analysis - We found 154 trees within the three studied plots, of which 72 were phorophytes ( $\sim 46.7 \%$ of total trees in all plots), from where the data about the horizontal and vertical distribution of epiphytic Bromeliaceae were obtained.

Regarding the horizontal distribution, we found only five species $(33 \%)$ in all three studied plots: Neoregelia farinosa, Nidularium azureum, Portea petropolitana, Quesnelia indecora and Tillandsia stricta, of which two also had the highest relative frequencies: $T$. stricta and $Q$. indecora. The two latter species, besides Aechmea nudicaulis, accounted for more than $50 \%$ of the occurrences (table 1). All three plots presented at least one exclusive species (Aechmea sp. and B. distachia in P1; Vriesea sp. 2 in $\mathrm{P} 2$ and B. horrida in P3).

Plots 1 and 2 had the greatest similarity between them, sharing nine species (four exclusive to these two plots) and presenting a Jaccard index of 0.64 (cophenetic coefficient of 0.98). As shown in figure 3, these plots had no significant difference concerning species richness. Plot 3 was the poorest with the lowest similarity index, in comparison with P1 (0.43) and P2 (0.46). The $H^{\prime}$ and $J$ values calculated for each plot were: P1 $\left(H^{\prime}=2.21, J=0.89\right), \mathrm{P} 2\left(H^{\prime}=2.04, J=0.85\right)$ and $\mathrm{P} 3\left(H^{\prime}=1.82, J=0.88\right)$. The Hutchinson t-test showed a significant difference only between P1 and P3 $(p=0.003)$.

Although the three plots are close to each other, differences among them regarding richness, similarity and diversity can be due to some differences in the microhabitat of the three plots. As a matter of fact, P1 presented higher density of trees $(n=59), P 2$ had the 
presence of bamboos, consequently with the lowest number of trees $(\mathrm{n}=44)$ and $\mathrm{P} 3$ also presenting trees $(\mathrm{n}=51)$, but with many palm trees, that in general, do not act as phorophytes and show apparently a closer canopy in comparison with the other two plots. As far as vertical distribution is concerned, we found 246 occurrences in all five strata, of which 101 were concentrated in the trunk. However, some species were restricted to only one part of the phorophyte, i.e., the trunk or crown. In the studied plots, Billbergia distachia, Vriesea gradata and Vriesea sp. 2 occur only in the trunk, while Aechmea sp., B. horrida and Portea petropolitana occur only in the crown. Quesnelia indecora, A. nudicaulis and Neoregelia farinosa (with 20, 13 and eight occurrences, respectively) were the most represented species in the trunk, whereas Tillandsia stricta and T. usneoides (with 35 and 10 occurrences, respectively) were the most numerous species in the crown (figure 2).

The trunk was the stratum that concentrated the largest number of occurrences (101), which declined toward the canopy, diverging from the findings of Kersten \& Silva (2002), Giongo \& Waechter (2004) and Dettke et al. (2008) who found that the crown presented the greatest richness. The upper strata, where there is more intense light exposure and the humidity is commonly lower. It also has more branches for the fixation of epiphytes; however, such branches are often newer and thinner, not allowing the establishment and development of several species (Kersten \& Silva 2002), especially bigger plants, such as some Aechmea and Vriesea species. In the case of the study area, the environment remains humid due to the proximity of the Cágado River, in addition to a canopy which is not too dense (pers. obs.). The gap created by the river allows good levels of light exposure, which does not require the species to occupy the highest points of the trees in search of light.

According to Benzing (1990), the vertical distribution of epiphytes in the forest is due to factors such as availability of space, light exposure and humidity. Environments closer to watercourses frequently have a higher occurrence of epiphytes because of the higher local humidity (Giongo \& Waechter 2004). In a study of Bromeliaceae flora in three areas composed of dense ombrophilous forest in São Paulo State, Fischer \& Araújo (1995) found greater richness and abundance close to the edge of the river. This proximity allows even those species that commonly inhabit shaded environments to tolerate higher light intensity if such sites have sufficient humidity, as observed closer to watercourses (Benzing 1995), a fact corroborated by Bonnet et al. (2007). Apparently, the same occurs in the studied plots, however a specific study comparing inner forest and sites adjacent to the river shall be performed to obtain more accurate conclusions.

The proximity to watercourses could also support dryer vegetations such as the seasonally semideciduous forest in FFS to have greater specific richness rather than some larger areas of moister vegetation of dense ombrophilous forests, even though the latter physiognomy is richer in vascular epiphytic plants (Kersten 2010).

Quantitative studies of Bromeliaceae are not available for seasonal forests, therefore the calculated diversity of epiphytic bromeliads in FFS is compared

Table 2 - Specific richness of Bromeliaceae in studies about vascular epiphytes in areas with seasonal semideciduous forest in the southeastern and southern regions of Brazil. States - MG: Minas Gerais; SP: São Paulo; PR: Paraná; RS: Rio Grande do Sul. NS: number of bromeliads species; A: extension of area. *: Ecotonal area between seasonal semideciduous forest and mixed ombrophilous forest; NP: number of surveyed phorophytes.

\begin{tabular}{lcccc}
\hline Site (State) & NS & Area & NP & References \\
\hline Fazenda Fortaleza de Sant'Anna (MG) & 15 & $\sim 0.3$ ha & 72 & Present study \\
Cidade Universitária Armando Salles Oliveira (SP) & 8 & $10.2 \mathrm{ha}$ & & Dislich \& Mantovani (1998) \\
Estreito Augusto César (RS) & 10 & $5.5 \mathrm{~km}$ & & Rogalski \& Zanin (2003) \\
Estação Ecológica Caetetus (SP) & 3 & $1.2 \mathrm{ha}$ & 1,287 & Breier (2005) \\
Parque Nacional do Iguaçu (PR) & 6 & 170,000 ha & & Cervi \& Borgo (2007) \\
Parque do Ingá (PR) & 7 & 47.3 ha & 90 & Dettke et al. (2008) \\
Horto Florestal Municipal de Erechim (RS)* & 2 & 0.4 ha & 499 & Bernardi \& Budke (2010) \\
Capela do Calvário (PR)* & 8 & 30 ha & 80 & Geraldino et al. (2010) \\
Floresta Nacional de Ipanema (SP) & 4 & 5,179 ha & 180 & Bataghin et al. (2012) \\
\hline
\end{tabular}




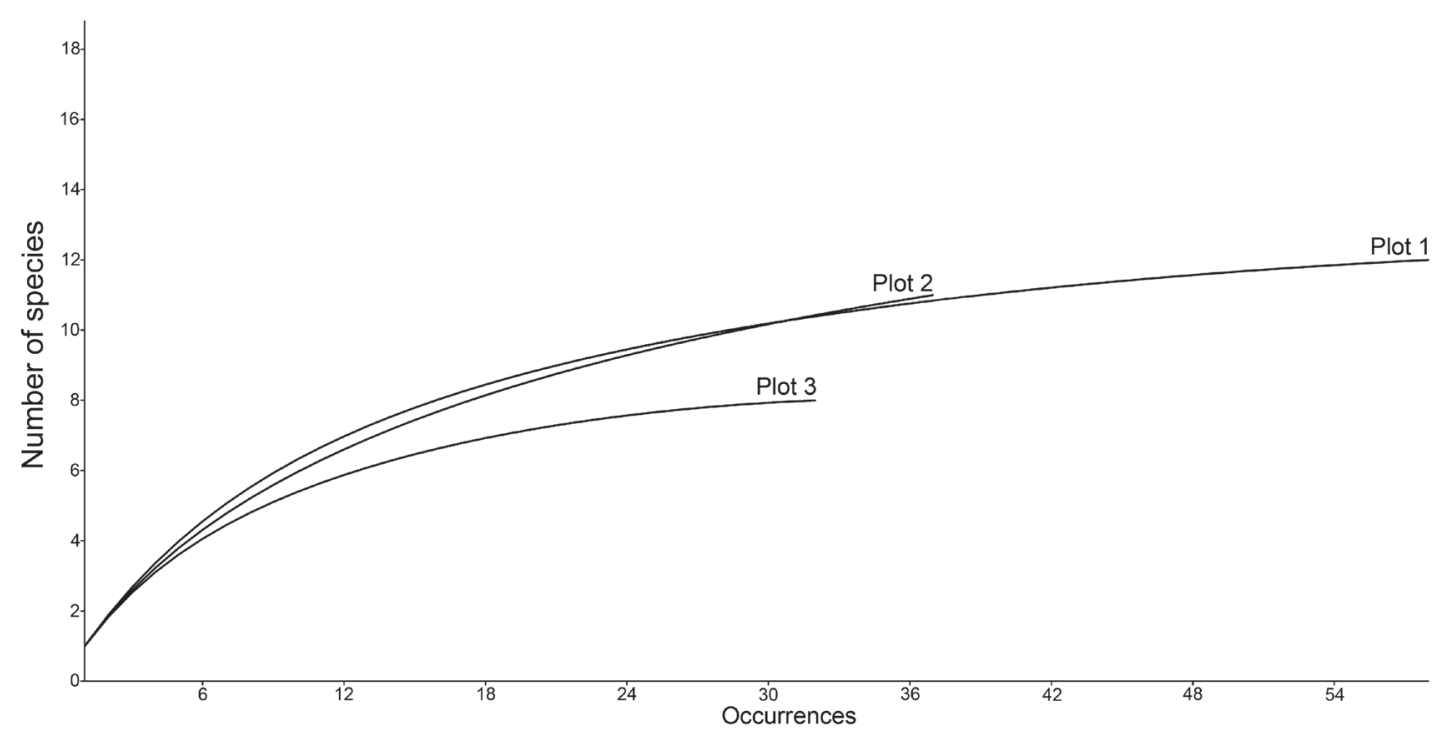

Figure 3. Rarefaction curves comparing the richness among the three plots. The curves of confidence intervals (95\%) were not showed to prevent confusion or misinterpretation with the rarefaction curves.

Table 3 - Comparison among richness (R), diversity $\left(H^{\prime}\right)$ and equitability $(J)$ found in three areas of primary dense ombrophilous forest and the present study, Minas Gerais State, Brazil. $\mathrm{P}(\mathrm{mm})$ : mean annual precipitation available in respective studies.

\begin{tabular}{lccccc}
\hline Reference & Site & $\mathrm{P}(\mathrm{mm})$ & $\mathrm{R}$ & $H^{\prime}$ & $J$ \\
\hline Present study & Chácara, MG & 1,581 & 15 & 2.34 & 0.87 \\
Almeida et al. (1998) & Ilha Grande, RJ & 2,240 & 17 & 1.61 & 0.59 \\
Rogalski (2002) & Florianópolis, SC & 1,527 & 13 & 1.95 & 0.76 \\
Hoeltgebaum (2003) & Ilhota, SC & 1,900 & 24 & 2.69 & 0.85 \\
\hline
\end{tabular}

with some studies performed in ombrophilous forests (table 3$)$. The alpha diversity $\left(H^{\prime}=2.34\right)$ was similar or even higher, but $J(0.87)$ was higher than all the compared studies. This high equitability contributes to raise the $H^{\prime}$ in FFS, although its richness is low in comparison with two of the other three areas. However, the lack of similar studies dealing with epiphytic Bromeliaceae in seasonal semideciduous forests complicates further comparisons, and the present study shall be considered as a starting point to this subject in other sites of Minas Gerais as well as in other Brazilian States.

\section{Conclusions}

Despite the small size of the studied area, the richness and diversity of Bromeliaceae in the Fazenda Fortaleza de Sant'Anna must be highlighted, due to the presence of more species than other places with larger areas and moister environments.
The high number of bromeliad species in a small area, besides the record of a population of Nidularium azureum, a microendemic and critically endangered species previous known only in its type locality, shows the relevance of conservation and studies performed in the remnants of Zona da Mata in Minas Gerais State. Especially because such region has been largely impacted by anthropogenic disturbances over the last centuries. The occurrence of Nidularium azureum in all three studied plots and its position among the five most frequent bromeliads in the area corroborates the importance of conservation measures towards this forest of Minas Gerais State in order to preserve its biodiversity in a sustainable manner.

Furthermore, the three studied plots showed some differences in composition, richness and similarity, despite the closeness among them, suggesting the existence of restricted microhabitats in the forest. These microhabitats are apparently independent of the proximity to the watercourse, since all the three plots are the same distance from the Cágado River. 
Finally, our findings also contributed to knowledge of epiphytes in the State of Minas Gerais, which is scarce and very significant as to the biodiversity conservation in such State as well as the whole country.

\section{Acknowledgements}

We wish to thank Mr. Octaviano Falci Menezes who granted us a license to conduct the study, to Rafaela C. Forzza who collaborated in identification of some species and to Proof Reading Services for the revision of English.

\section{Literature cited}

Almeida, D.R., Carvalho, L.C. \& Rocha, C.F.D. 1998. As bromélias da Mata Atlântica da Ilha Grande, RJ: Composição e diversidade de espécies em três ambientes diferentes. Bromélia 5: 55-65.

Alves, F.E. \& Menini Neto, L. 2014. Vascular epiphytes in a forest fragment of Serra da Mantiqueira and floristic relationships with Atlantic high altitude areas in Minas Gerais. Brazilian Journal of Botany 37: 187-196.

Alves, R.J.V., Kolbek, J. \& Becker, J. 2008. Vascular epiphyte vegetation in rocky savannas of southeastern Brazil. Nordic Journal of Botany 26: 101-117.

Bataghin, F.A., Pires, J.S.R. \& Barros, F. 2012. Epifitismo vascular em sítios de borda e interior em Floresta Estacional Semidecidual no Sudeste do Brasil. Hoehnea 39: 235-245.

Barbosa, D.E.F., Basílio, G.A., Silva, F.R. \& Menini Neto, L. 2015. Vascular epiphytes in a remnant of Seasonal Semideciduous Forest in the Zona da Mata, state of Minas Gerais, Brazil. Bioscience Journal 31: 623-633.

Benzing, D.H. 1990. Vascular epiphytes. Cambridge University Press, Cambridge.

Benzing, D.H. 1995. Vascular Epiphytes in Forest Canopies. In: M.D. Lowman \& N.M. Nadkarni (eds.). Forest canopies, 1st ed. Academic Press, San Diego, pp. 225-254.

Benzing, D.H. 2000. Bromeliaceae: Profile of an Adaptive Radiation. Cambridge University Press, Cambridge.

Bernardi, S. \& Budke, J.C. 2010. Estrutura da sinúsia epifítica e efeito de borda em uma área de transição entre Floresta Estacional Semidecidual e Floresta Ombrófila Mista. Floresta 40: 81-92.

Bianchi, J.S., Bentos, C.M. \& Kersten, R.A. 2012. Epífitas vasculares de uma área de ecótono entre as Florestas Ombrófilas Densa e Mista, no Parque Estadual do Marumbi, PR. Estudos de Biologia 34: 37-44.

Bonnet, A., Queiroz, M.H. \& Lavoranti, O.J. 2007. Relações de Bromélias epifíticas com características dos forófitos em diferentes estádios sucessionais da Floresta Ombrófila Densa, Santa Catarina, Brasil. Floresta 37: 83-94.
Bonnet, A., Curcio, G.R., Lavoranti, O.J. \& Galvão, F. 2011. Flora epifítica vascular em três unidades de vegetacionais do Rio Tibagi, Paraná, Brasil. Rodriguésia 62: 491-498.

Breier, T.B. O epifitismo vascular em florestas do sudeste do Brasil. 2005. Tese de Doutorado, Universidade Estadual de Campinas, Campinas.

Buzatto, C.R., Severo, B.M.A. \& Waechter, J.L. 2008. Composição florística e distribuição ecológica de epífitos vasculares na Floresta Nacional de Passo Fundo, Rio Grande do Sul. Iheringia, Série Botânica 63: 231-239.

Cervi, A.C. \& Borgo, M. 2007. Epifitos Vasculares no Parque Nacional do Iguaçu, Paraná (Brasil). Levantamento Preliminar. Fontqueria 55: 415-422.

Dettke, G.A., Orfrini, A.C. \& Milaneze-Gutierre, M.A. 2008. Composição e distribuição de epífitas vasculares em um remanescente alterado de Floresta Estacional Semidecidual no Paraná, Brasil. Rodriguésia 59: 859-872.

Dislich, R. \& Mantovani, W. 1998. A Flora de epífitas vasculares da Reserva da Cidade Universitária "Armando de Salles Oliveira" (São Paulo, Brasil). Boletim de Botânica da Universidade de São Paulo 17: 61-83.

Dittrich, V.A.O., Kozera, C. \& Menezes-Silva, S. 1999 , Levantamento Florístico dos epífitos vasculares do Parque Barigüi, Curitiba. Iheringia, Série Botânica 52: 11-21.

Drummond, G.M., Soares, C.S., Machado, A.B.M., Sebaio, F.A. \& Antonini, Y. (orgs.). 2005. Biodiversidade em Minas Gerais: um atlas para sua conservação. $2^{\mathrm{a}}$ ed. Fundação Biodiversitas, Belo Horizonte.

Fabricante, J.R., Andrade, L.A. \& Marques, F.J. 2006. Componente epífito vascular em árvores urbanas. Cerne 12: 399-405.

Fischer, E.A. \& Araújo, A. 1995. Spatial organization of a bromeliad community in the Atlantic rainforest, southeastern Brazil. Journal of Tropical Ecology 11: 559-567.

Fontoura, T., Rocca, M.A., Schilling, A.C. \& Reinert, F. 2009. Epífitas da Floresta Seca da Reserva Ecológica Estadual de Jacarepiá, Sudeste do Brasil: Relações com a comunidade arbórea. Rodriguésia 60: 171-185.

Fontoura, T., Scudeller, V.V. \& Costa, A.F. 2012. Floristics and environmental factors determining the geographic distribution of epiphytic bromeliads in the Brazilian Atlantic Rain Forest. Flora 207: 662-672.

Forzza, R.C., Baumgratz, J.F., Bicudo, C.E.M., Canhos, D.A.L., Carvalho Jr., A.A., Coelho, M.A.N., Costa, A.F., Costa, D.P., Hopkins, M.G., Leitman, P.M., Lohmann, L.G., Lughadha, E.M., Maia, L.C., Martinelli, G., Menezes, M., Morim, M.P., Peixoto, A.L., Pirani, J.R., Prado, J., Queiroz, L.P., Souza, S., Souza, V.C., Stehmann, J.R., Sylvestre, L.S., Walter, B.M.T. \& Zappi, D.C. 2012. New Brazilian floristic list highlights conservation challenges. BioScience 62: 39-45. 
Forzza, R.C., Costa, A.F., Leme, E.M.C., Versieux, L.M., Wanderley, M.G.L., Louzada, R.B., Monteiro, R.F, Judice, D.M., Fernandez, E.P., Borges, R.A.X., Penedo, T.S.A, Monteiro, N.P., Moraes, M.A. 2013. Bromeliaceae. In: G. Martinelli \& Moraes, M.A. (eds.). Livro vermelho da flora do Brasil. Instituto de Pesquisas Jardim Botânico do Rio de Janeiro, Rio de Janeiro, pp. 315-396.

Forzza, R.C., Costa, A., Siqueira Filho, J.A., Martinelli, G., Monteiro, R.F., Santos-Silva, F., Saraiva, D.P., Paixão-Souza, B. 2014. Bromeliaceae. In: Lista de Espécies da Flora do Brasil. Jardim Botânico do Rio de Janeiro, 2014. Available in http://floradobrasil.jbrj. gov.br/jabot/floradobrasil/FB66. (access in 08-II-2014).

Forzza, R.C., Pifano, D.S., Oliveira-Filho, A.T., Meireles, L.D., Faria, P.L., Salimena, F.R., Mynssen, C.M. \& Prado, J. 2014. Flora vascular da Reserva Biológica da Represa do Grama, Minas Gerais, e sua relação florística com outras florestas do sudeste brasileiro. Rodriguésia 65: 275-292.

Gaiotto, D.F. \& Acra, L.A. 2005. Levantamento qualitativo de epífitos da Fazenda Gralha Azul - Fazenda Rio Grande - Paraná. Revista Estudos de Biologia 27: 25-32.

Geraldino, H.C.L., Caxambú, MG. \& Souza, D.C. 2010. Composição florística e estrutura da comunidade de epífitas vasculares em uma área de ecótono em Campo Mourão, PR, Brasil. Acta Botanica Brasilica 24: 469-482.

Giongo, C. \& Waechter, J.L. 2004. Composição florística e estrutura comunitária de epífitos em uma floresta de galeria na Depressão Central do Rio Grande do Sul. Revista Brasileira de Botânica 27: 563-572.

Givnish, T.J., Barfuss, M.H.J., Van Ee, Riina, R., Schulte, K., Horres, R., Gonsiska, P.A., Jabaily, R.S., Crayn, D.M., Smith, A.C., Winter, K., Brown, G.K., Evans, T.M., Holst, B.K., Luther, H., Till, W., Zizka, G., Berry, P.E. \& Systma, K.J. 2011. Phylogeny, adaptive radiation, and historical biogeography in Bromeliaceae: insights from an eightlocus plastid phylogeny. American Journal of Botany 98: 872-895.

Gonçalves, C.N. \& Waechter, J.L. 2003. Aspectos florísticos e ecológicos de epífitos vasculares sobre figueiras isoladas no norte da planície costeira do Rio Grande do Sul. Acta Botanica Brasilica 17: 89-100.

Hammer, Ø., Harper, D.A.T. \& Ryan, P.D. 2001. PAST: paleontological Statistics software package for education and data analysis. Palaeontologia Electronica 4: $1-9$.

Hobus, Q., Soares, L.R., Largue, C.M. \& Duarteda-Silva, P.A. 2008. Análise da estrutura vertical da comunidade epifítica de Erythrina cristagalli L. em uma mata paludosa da BR 392, trecho Pelotas-Rio Grande, RS. In: Anais do XVII Congresso de Iniciação Científica e X Encontro de Pós-Graduação. Universidade Federal de Pelotas, Pelotas. Available in http://www.ufpel.edu. br/cic/2008/cd/pages/pdf/CB/CB_01487.pdf. (access in 06-V-2013).
Hoeltgebaum, M.P. 2003. Composição florística e distribuição espacial de bromélias epifíticas em diferentes estágios sucessionais da Floresta Ombrófila Densa, Parque Botânico Morro do Baú, Ilhota, SC. Dissertação de Mestrado, Universidade Federal de Santa Catarina, Florianópolis.

IPNI. 2012. The International Plant Names Index. http:// www.ipni.org. (access in 19.10.2012).

Kersten, R.A. 2010. Epífitas vasculares - Histórico, participação taxonômica e aspectos relevantes, com ênfase na Mata Atlântica. Hoehnea 37: 9-38.

Kersten, R.A. \& Silva, S.M. 2002. Florística e estrutura do componente epifítico vascular em Floresta Ombrófila Mista Aluvial do Rio Barigüi, Paraná, Brasil. Revista Brasileira de Botânica 25: 259-267.

Kersten, R.A. \& Waechter, J.L. 2009. Capítulo 8: Métodos quantitativos no estudo de comunidades epifíticas. In: J.M. Felfili, P.V. Eisenlohr, M.M.R.F. Melo, L.A. Andrade, \& J.A.A. Meira Neto (eds.). Fitossociologia no Brasil - métodos e estudos de casos. Editora UFV, Viçosa, v. 1, pp. 231-254.

Magurran, A.E. 2011. Medindo a diversidade biológica. Editora UFPR, Curitiba.

Mania, L.F. \& Monteiro, R. 2010. Florística e ecologia de epífitas vasculares em um fragmento de Floresta de Restinga, Ubatuba, SP. Rodriguésia 61: 705-713.

Martinelli, G., Vieira, C.M., Gonzales, M., Leitman, P., Piratininga, A., Costa, A.F. \& Forzza, R.C. 2008. Bromeliaceae da Mata Atlântica Brasileira: lista de espécies, distribuição e conservação. Rodriguésia 59: 209-258.

Menini Neto, L., Forzza, R.C. \& Zappi, D. 2009a. Angiosperm epiphytes as conservation indicators in forest fragments; a case study from southeastern Minas Gerais, Brazil. Biodiversity and Conservation 18: 3785-3807.

Menini Neto, L., Matozinhos, C.N., Abreu, N.L., Valente, A.S.M., Antunes, K., Souza, F.S., Viana, P.L. \& Salimena, F.R.G. 2009b. Flora vascular não arbórea de uma floresta de grota na Serra da Mantiqueira, Zona da Mata de Minas Gerais, Brasil. Biota Neotropica 9: 149-161.

Ministério do Meio Ambiente. 2013. Biomas - Mata Atlântica. Available in http://www.mma.gov.br/biomas/ mata-atlantica. (access in 06-V-2013).

Myers, N., Mittermeier, R.A., Mittermeier, C.G., Fonseca, G.A.B. \& Kent, J. 2000. Biodiversity hotspots for conservation priorities. Nature 403: 853-858.

Perleberg, T.D. \& Tomkowski, P.B.P. 2007. Bromeliaceae e Orchidaceae Epífitas nas Trilhas do Ecocamping Municipal de Pelotas, RS, Brasil. Revista Brasileira de Biociências 5: 720-722.

Pifano, D.S., Valente, A.S.M., Castro, R.M., Pivari, M.O.D., Salimena, F.R.G. \& Oliveira-Filho, A.T. 2007. Similaridade entre os habitats da vegetação do Morro do Imperador, Juiz de Fora, Minas Gerais, com base na composição de sua flora fanerogâmica. Rodriguésia 58: 885-904. 
Pinto, A.C., Demattê, M.E.S.P. \& Pavani, M.C.M.D. 1995. Composição florística de epífitas (Magnoliophyta) em fragmento de floresta no município de Jaboticabal. Científica 22: 283-289.

PREA (Programa de Educação Ambiental). 2012. Fazenda Fortaleza de Sant'Anna: trilhando um caminho para a conservação (Relatório Técnico). Programa de Educação Ambiental, Juiz de Fora.

Reitz, R. 1983. Bromeliáceas e a Malária - Bromélia Endêmica. Flora Ilustrada Catarinense, Fasc. Brom. Ed. Raulino Reitz, Itajaí.

Ribeiro, M.C., Metzger, J.P., Martensen, A.C., Ponzoni, F.J. \& Hirota, M.M. 2009. The Brazilian Atlantic Forest: how much is left, and how is the remaining forest distributed? Implications for conservation. Biological Conservation 142: 1141-1153.

Rogalski, J.M. 2002. Distribuição espacial de bromélias e aráceas epifíticas em diferentes situações topográficas em Floresta Ombrófila Densa, Ilha de Santa Catarina, SC. Dissertação de Mestrado, Universidade Federal de Santa Catarina, Florianópolis.

Rogalski, J.M. \& Zanin, E.M. 2003. Composição florística de epífitos vasculares no estreito de Augusto César, Floresta Estacional Decidual do Rio Uruguai, RS, Brasil. Revista Brasileira de Botânica 26: 551-556.

Sano, P.T. , Forzza, R.C., Giulietti, A.M., Sakuragui, C.M., Fraga, C.N., Leme, E.M.C., Costa, F.N., Fernandes, H.Q.B., Andrade, I.R., Batista, J.A.N., Nunes, J.V.C., Dutihl, J.H.A., Menini Neto, L., Alves, M.V.S., Trovó, M., Coelho, M.A.N., Assis, M.C., Viana, P.L., Reis, R.C.C., Mota, R.C., Filgueiras, T.S. 2008. Monocotiledôneas Ameaçadas de Extinção no Estado de Minas Gerais. In: G.M. Drummond, A.B.M. Machado; C.S. Martins; M.P. Mendonça \& J.R. Stehmann. (orgs.). Listas Vermelhos das Espécies da Fauna e da Flora Ameaçada de Extinção em Minas Gerais (CD-Rom). 2ed. Biodiversitas, Belo Horizonte.
Saraiva, L.F. 2005. Estrutura de terras e transição do trabalho em um grande centro cafeeiro, Juiz de Fora, 1870-1900. Revista Científica da FAMINAS 2: $179-212$.

Smith, L. 1934. Geographical evidence on the lines of evolution in the Bromeliaceae. Botanisch Jahrbücher für Systematik 66: 446-468

Smith, L.B. \& Downs, R.J. 1974. Pitcairnioideae (Bromeliaceae). Flora Neotropica Monograph 14: 1-658.

Stehmann, J.R., Forzza, R.C., Salino, A., Sobral, M., Costa, D.P. \& Kamino, L.H.Y. (orgs.). 2009. Plantas da Floresta Atlântica. Jardim Botânico do Rio de Janeiro, Rio de Janeiro.

The Plant List. 2013. Version 1.1. Published on the internet. Available in http://www.theplantlist.org/. (access in 08-II-2014).

Thiers, B. [continuously updated]. 2013. Index Herbariorum: A global directory of public herbaria and associated staff. New York Botanical Garden's Virtual Herbarium. Available in http://sweetgum.nybg.org/ih/. (access in 01-XI-2012).

Valverde, O. 1958. Estudo regional da Zona da Mata de Minas Gerais. Revista Brasileira de Geografia 20: 1-82.

Veloso, H.P., Rangel Filho, A.L.R. \& LIMA, J.C. 1991. A classificação da vegetação brasileira adaptada a um sistema universal. IBGE, Rio de Janeiro.

Versieux, L.M. \& Wendt, T. 2007. Bromeliaceae diversity and conservation in Minas Gerais State, Brazil. Biodiversity and Conservation 16: 2989-3009.

Werneck, M.S. \& Espírito-Santo, M.M. 2002. Species diversity and abundance of vascular epiphytes on Vellozia piresiana in Brazil. Biotropica 34: 51-57.

Zotz, G. 2013. The systematic distribution of vascular epiphytes - a critical update. Botanical Journal of the Linnean Society 171: 453-481. 